\title{
PEMBUATAN FRUIT LEATHER DENGAN CAMPURAN BUAH NAGA MERAH (HylocereuS polyrhizus) DAN BUAH PISANG KEPOK (Musa Paradisiaca)
}

\author{
[Processing of Fruit Leather from Mixture of Red Dragon (Hylocereus polyrhizus) Fruit and \\ Banana (Musa Paradisiaca)]
}

\author{
Khurfatul Jannah*, Afe Dwiani dan Suburi Rahman \\ Program Studi Teknologi Hasil Pertanian, Fakultas Pertanian, Universitas Nahdlatul Wathan Mataram \\ *Email: khurfatul_j@yahoo.com
}

Diterima 11 Maret 2019 / Disetujui 22 Mei 2019

\begin{abstract}
Red dragon fruit are a fruit that have a high antioxidants while banana are fruits that have a high carbohydrate and dietary fiber. Fruits are easy to spoil because of their properties are perishable and the way to increase shelf life is by processing it into fruit leather. Fruit leather is a snack that made from fruit and dried so they have a plastic and chewy texture. Besides that, processing fruit can also diversified fruit processing product. The aims of this research was to determine the best combination of red dragon fruit with banana in making fruit leather. The method that used in this study was a completely randomized design (CRD) with a single factor, consisting 5 treatment $P 1=$ dragon fruit 100\%: banana 0\%; $P 2=$ dragon fruit $75 \%$ : banana $25 \% ; P 3=$ dragon fruit 50\%: banana 50\%; P4 = dragon fruit 25\%: banana 75\% and P5 = dragon fruit 0\%: banana $100 \%$ with 3 times repetitions. The data of the research were analyzed using Analysis of Variance at alpha 5\% using SPSS 16 and tested continued using the test of Honest Real Difference (HRD) if there was real difference. The results showed that processing of fruit leather from mixture of red dragon fruit and bananas gave a significantly difference effect on chemical quality (moisture content and vitamin C) but gave not significant effect on ash content. Fruit leather with a mixture of red dragon fruit and banana that suitable with SNI No. 1718-83 for moisture content ( $<25 \%$ ) are treatments P1, P4 and P5, respectively $24.24 \% ; 21.8 \%$ and $23.30 \%$. The highest vitamin $C$ was produced in treatment $P 1$, which was $84.07 \mathrm{mg} / \mathrm{g}$.
\end{abstract}

Keywords: dragon fruit, fruit leather, banana

\section{ABSTRAK}

Buah naga merah merupakan buah yang memiliki kandungan antioksidan yang tinggi, sedangkan buah pisang merupakan buah yang mengandung karbohidrat dan serat tinggi. Buah mudah mengalami kerusakan dan cara yang digunakan untuk meningkatkan masa simpannya adalah dengan cara mengolahnya menjadi Fruit Leather. Fruit leather merupakan makanan yang berasal dari buah yang dihancurkan dan dikeringkan dengan tekstur plastik dan kenyal serta rasa yang manis. Selain itu pengolahan juga dapat menganekaragamkan produk olahan buah-buahan. Penelitian ini bertujuan untuk mengetahui kombinasi terbaik dari buah naga merah dengan pisang kepok dalam pembuatan fruit leather. Metode yang digunakan dalam penelitian ini adalah rancangan acak lengkap dengan faktor tunggal yaitu konsentrasi buah naga merah dan pisang kepok ( $\mathrm{P} 1=$ buah naga $100 \%$ : pisang kepok $0 \% ; \mathrm{P} 2=$ buah naga $75 \%$ :pisang kepok $25 \%$; $\mathrm{P} 3=$ buah naga $50 \%$ :pisang kepok $50 \%$; $\mathrm{P} 4=$ buah naga $25 \%$ :pisang kepok $75 \%$ dan $\mathrm{P} 5=$ buah naga $0 \%$ :pisang kepok $100 \%$ ) dengan 3 kali ulangan. Parameter yang diamati dalam penelitian ini adalah kadar kimia yang meliputi kadar air, kadar abu dan kadar vitamin C. Data hasil penelitian dianalisis menggunakan analisis keragaman (Analysis of Variance) pada taraf nyata 5\% dengan menggunakan SPSS 16 dan apabila terdapat beda nyata dilakukan uji lanjut dengan Uji Beda Nyata Jujur (BNJ). Hasil penelitian menunjukkan bahwa perlakuan penambahan buah naga merah dan pisang kepok berpengaruh terhadap kadar air dan kadar vitamin C. Fruit leather dengan campuran buah naga merah dan pisang kepok yang memenuhi standar SNI No. 1718-83 untuk kadar air ( $<25 \%$ ) adalah perlakuan P1, P4 dan P5 berturut-turut sejumlah 24,24\%; 21,8\% dan 23,30\%. Kadar vitamin C tertinggi dihasilkan pada perlakuan P1 yaitu $84,07 \mathrm{mg} / \mathrm{g}$.

Keywords: fruit leather, buah naga, pisang kepok, air, abu, vitamin C

\section{PENDAHULUAN}

Buah-buahan merupakan jenis bahan pangan yang memiliki kandungan gizi yang lengkap yang dibutuhkan oleh tubuh manusia seperti karbohidrat, lemak, protein, vitamin, dan kandungan lainnya. Namun pola hidup masyarakat di Indonesia belum memiliki kesadaraan untuk mengkonsumsi buahbuahan. Salah satu upaya penganekaragaman 
Versi Online:

http://www.profood.unram.ac.id/index.php/profood e-ISSN: 2443-3446

olahan buah adalah fruit leather (Astuti et al., 2015).

Fruit leather merupakan produk manisan kering dari buah-buahan yang diawetkan dengan gula pada konsentrasi tertentu. Selain itu, biaya penanganan, pengangkutan, dan penyimpanan relatif rendah karena lebih ringan (Elizabeth et al., 2006). Fruit leather berbentuk lembaran tipis yang mempunyai konsistensi dan rasa khas (Puspasari et al.,2005). Salah satu komoditi yang potensiall untuk dikembangkan dalam pembuatan fruit leather adalah buah naga merah dan pisang kepok.

Kandungan zat gizi buah naga merah, yaitu: air $(82,5 \mathrm{~g}-83,0 \mathrm{~g})$, protein $(0,16 \mathrm{~g}$ $0,23 \mathrm{~g})$, lemak $(0,21 \mathrm{~g}-0,61 \mathrm{~g})$, betakaroten $(0,005 \mathrm{mg}-0,012 \mathrm{mg})$, kalsium $(6,3 \mathrm{mg}-8,8$ $\mathrm{mg})$, fosfor $(30,2 \mathrm{mg}-36,1 \mathrm{mg})$, besi $(0,55$ $\mathrm{mg}-0,65 \mathrm{mg})$, vitamin B1 $(0,28 \mathrm{mg}-0,30$ $\mathrm{mg})$, vitamin B2 $(0,043 \mathrm{mg}-0,045 \mathrm{mg})$, vitamin C $(8 \mathrm{~g}-9 \mathrm{~g})$ dan niasin $(1,297 \mathrm{mg}$ $1,300 \mathrm{mg}$ ) (Taiwan Food Industry Develop \& Reearch Authorities, 2005). Selain zat gizi, buah naga merah juga mengandung fitokimia yang baik bagi tubuh, diantaranya flavonoid. Kandungan flavonoid pada daging buah naga merah sebanyak 7,21 \pm 0,02 mg CE/100 gram (Wu dan Prentice, 2005). Buah-buahan yang baik digunakan sebagai bahan baku untuk pembuatan fruit leather adalah buah-buahan yang memiliki serat dan memiliki aroma yang khas, salah satunya adalah pisang. Menurut Wahyuni (2015) pisang kepok mengandung karbohidrat yang tinggi $(31,04 \%)$, protein $(1,75 \%)$ maupun serat kasar $(1,14 \%)$. Selain itu pisang kepok juga memiliki aktifitas antioksida sebesar 12,35\%.

Berdasarkan uraian di atas maka telah dilakukan penelitian mengenai pembuatan fruit leather dengan campuran buah naga merah (Hylocereus polyrhizus) dan buah pisang kepok (Musa Paradisiaca). Penelitian ini bertujuan untuk mendapatkan kombinasi yang tepat dari buah naga merah dan pisang kepok dalam pembuatan fruit leather agar dapat diterima oleh masyarakat.

\section{BAHAN DAN METODE}

\section{Alat dan Bahan}

Pro Food (Jurnal IImu dan Teknologi Pangan)

Vol 5 No. 1 Mei 2019

ISSN: 2443-1095

Alat-alat yang digunakan dalam penelitian ini antara lain termometer, loyang, pisau, panci, spatula plastik, timbangan analitik, oven kabinet lampu, erlenmeyer, nampan, pipet, gelas piala, desikator, labu ukur, kertas saring, kompor gas, cawan, furnace, kertas label, tissu dan alat tulis.

Bahan-bahan yang digunakan dalam penelitian ini adalah buah naga merah dan pisang kepok (dengan kematangan masingmasing buah sebesar 80\%) diperoleh dari pasar kebon roek Ampenan. Gula, asam sitrat dan agar-agar merek Nutrijell diperoleh di Toko Kue Yaoya. Bahan lainnya adalah aquades, amilum $1 \%$, dan yodium $0,01 \mathrm{~N}$.

\section{Metode}

Metode penelitian yang digunakan dalam penelitian ini adalah metode eksperimental dengan percobaan di Laboratorium. Rancangan penelitian yang digunakan adalah Rancangan Acak Lengkap (RAL) dengan faktor tunggal dengan lima konsentrasi buah naga merah dan pisang kepok.

Masing-masing perlakuan diulang sebanyak tiga kali sehingga diperoleh 15 unit percobaan. Data hasil pengamatan di analisis dengan analisa keragaman (Analysis of Variance) pada taraf nyata $5 \%$ dengan menggunakan software Co-Stat. Apabila terdapat beda nyata, dilakukan uji lanjut menggunakan uji Beda Nyata Jujur (BNJ) pada taraf yang sama (Hanafiah, 2002). Parameter yang dianalisa adalah kadar air dan kadar abu (Sudarmadji et al., 2007) serta kadar vitamin C (AOAC, 1990).

\section{Proses Pembuatan Fruit Leather (Safitri, 2012 dengan modifikasi)}

1. Persiapan bahan baku

Bahan-bahan yang digunakan yaitu buah naga dan pisang kapok, masing-masing ditimbang sebanyak 100 gram (buah naga dan pisang kepok hanya dibersihkan dan dikuliti). Konsentrasi bahan tambahan lain yang digunakan dalam penelitian ini adalah gula $40 \%(40 \mathrm{~g})$, asam sitrat $0,1 \%(0,1 \mathrm{~g})$ dan agar-agar $10 \%(10 \mathrm{~g})$.

2. Penghancuran dan Pencampuran 
Versi Online:

http://Www.profood.unram.ac.id/index.php/profood e-ISSN: 2443-3446

Bahan dihancurkan menggunakan blender dengan tambahan air. Bahan tambahan lain seperti gula, asam sitrat dan agar-agar dicampur ke dalam sari buah.

3. Pemasakan

Bahan yang sudah tercampur rata kemudian dimasak pada suhu $70-80^{\circ} \mathrm{C}$ selama 5 menit.

4. Pencetakan

Setelah pemasakan, fruit leather kemudian dicetak dalam loyang ukuran $18 \mathrm{~cm} \times 9 \mathrm{~cm}$ dengan ketebalan 2-3 mm.

5. Pengeringan

Fruit leather kemudian dikeringkan menggunakan oven kabinet lampu pada suhu $45^{\circ} \mathrm{C}$ selama 14 jam.

6. Pemotongan

Fruit leather yang telah kering kemudian dipotong dengan ukuran $3 \times 1,5 \mathrm{~cm}$ menggunakan pisau stainless still. Proses pembuatan fruit leather dapat dilihat pada Gambar 1.

Buah Naga Merah

Buah Pisang Kepok

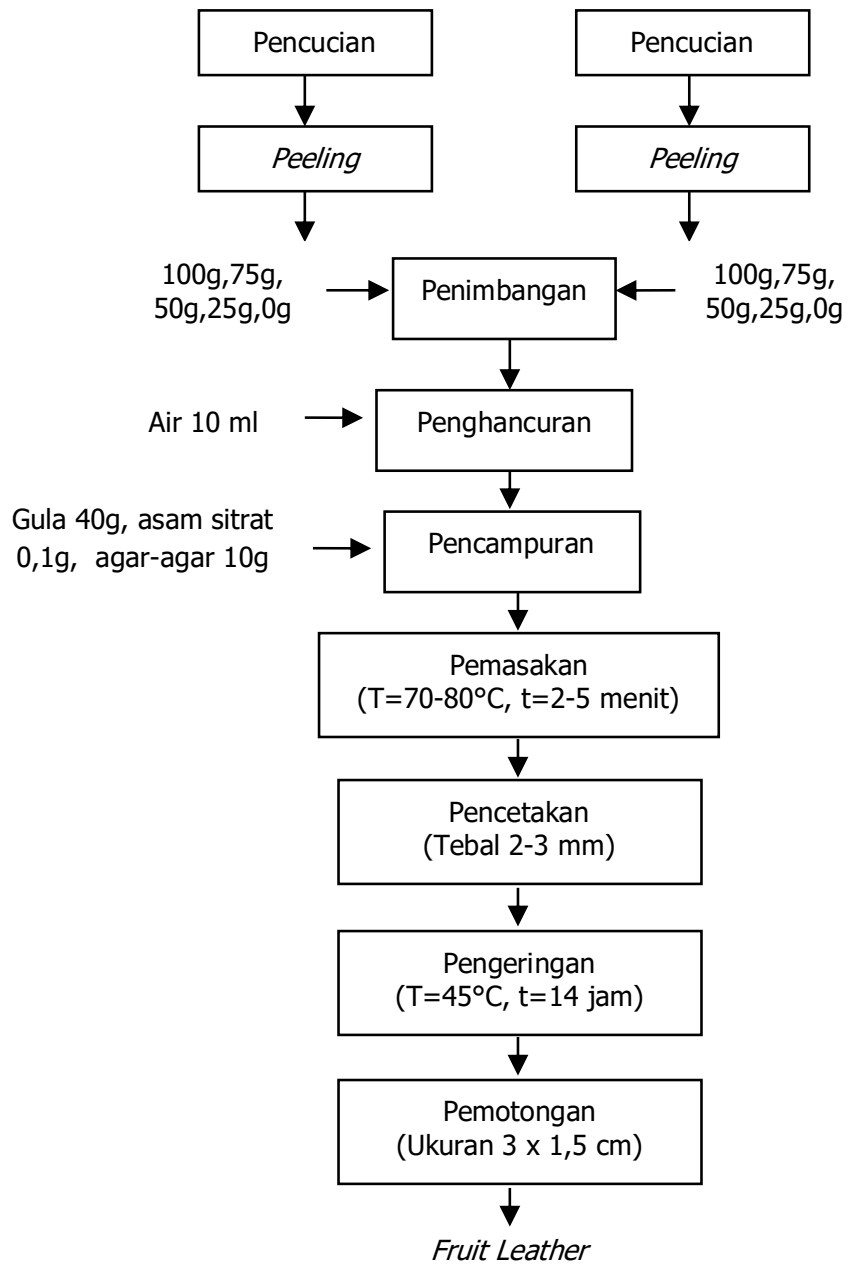

Pro Food (Jurnal Ilmu dan Teknologi Pangan)

Vol 5 No. 1 Mei 2019

ISSN: 2443-1095

Gambar 1. Diagram Alir Pembuatan Fruit Leather (Sumber: Safitri, 2012 dengan modifikasi)

\section{HASIL DAN PEMBAHASAN}

\section{Mutu Kimia}

Parameter yang diteliti dalam penelitian ini adalah kadar air, kadar abu dan kadar vitamin ini. Ketiga parameter ini dipilih berdasarkan Standar Nasional Indonesia No. 1718-83 tentang manisan buah-buahan kering.

\section{Kadar Air}

Kadar air merupakan salah satu karakteristik yang sangat penting bagi bahan pangan, karena kandungan air pada bahan pangan dapat mempengaruhi penampakan dan tekstur pada bahan pangan (Winarno, 2004). Penelitian ini menghasilkan fruit leather dengan kadar air berkisar antara 21,8\%$38,59 \%$. Grafik pengaruh konsentrasi campuran buah naga merah dan pisang kepok terhadap kadar air fruit leather dapat dilihat pada Gambar 2.

Gambar 2 menunjukkan bahwa campuran buah naga merah dan pisang kepok memberikan pengaruh nyata terhadap kadar air fruit leather dengan rataan kadar air berkisar antara 21,9\%-38,59\%. Kadar air pada perlakuan P2 (Buah naga 75\%: Pisang 25\%) merupakan perlakuan dengan kadar air tertinggi yaitu $38,59 \%$.

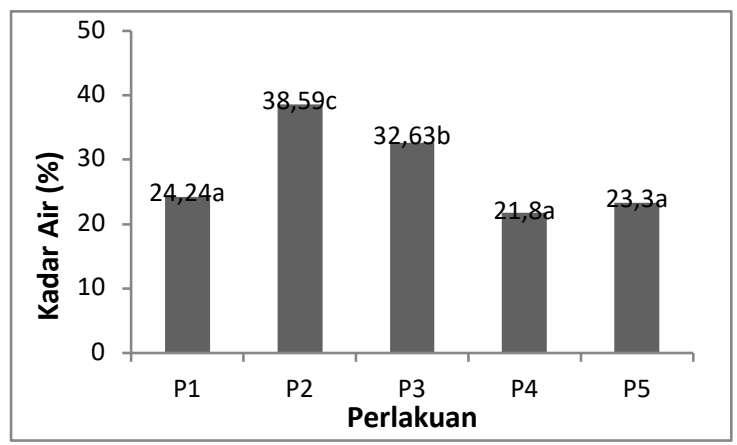

Gambar 2. Pengaruh Konsentrasi Campuran Buah Naga Merah dan Pisang Kepok Terhadap Kadar Air Fruit Leather

Keterangan: P1: Buah naga 100\%: Pisang 0\%; P2: Buah naga 75\%: Pisang 25\%; P3: Buah naga 50\%: Pisang 
50\%; P4: Buah naga 25\%: Pisang 75\%; P5: Buah naga $0 \%$ : Pisang $100 \%$

Hal ini dikarenakan daging buah dari buah naga merah segar memiliki kadar air cukup tinggi yaitu sebesar $82,5-83,0 \%$ (Taiwan Food Industry Develop \& Reearch Authorities, 2005 dalam Patwary, 2013). Kadar air cenderung mengalami penurunan seiring dengan berkurangnya konsentrasi buah naga merah yang ditambahkan. Ramadhan (2015) melaporkan bahwa kadar air fruit leather yang terbuat dari campuran buah naga merah dan mangga dipengaruhi oleh kandungan air pada bahan baku yang digunakan.

Pada grafik di atas terlihat bahwa semakin tinggi konsentrasi buah pisang kepok yang ditambahkan maka semakin rendah kadar air yang dihasilkan. Hal ini dikarenakan pisang kepok mengandung serat. Kadar serat kasar pada pisang kepok adalah 1,14\%. Menurut Praseptiangga et al. (2016) kehadiran serat atau polisakarida dalam bahan juga berpengaruh pada proses penyerapan air. Serat dapat meningkatkan kemampuan menyerap air. Menurut Karyantina et al. (2012) kadar air terendah $(25,85 \%)$ terdapat pada perlakuan fruit leather dengan bahan pisang kepok serta kenampakan pisang kepok yang lebih kering dibandingkan jenis pisang yang lain.

Perlakuan yang sesuai kadar air maksimal (maks. 25\%) berdasarkan SNI 011718-1996 untuk manisan kering buah-buahan adalah perlakuan P1 (Buah naga 100\%: Pisang 0\%), P4 (Buah naga 25\%: Pisang 75\%) dan P5 (Buah naga 0\%: Pisang 100\%).

\section{Kadar abu}

Kadar abu adalah unsur mineral atau zat anorganik yang tidak terbakar pada saat pembakaran (Winarno, 2004). Penelitian ini menghasilkan fruit leather dengan kadar abu bervariasi antara 1,35\%-2,06\%. Grafik pengaruh konsentrasi campuran buah naga merah dan pisang kepok terhadap kadar abu fruit leather dapat dilihat pada Gambar 3.

Pada Gambar 3 menunjukkan bahwa pengaruh campuran buah naga merah dan
ISSN: 2443-1095

pisang kepok tidak berbeda nyata terhadap kadar abu fruit leather.

Dari Gambar 3 dapat dilihat bahwa semakin tinggi konsentrasi campuran pisang kepok maka kadar abu yang dihasilkan semakin meningkat. Hal ini dikarenakan kandungan mineral bahan baku fruit leather baik pisang kepok maupun buah naga merah.

Buah pisang kepok matang mengandung mineral yang lebih tinggi seperti kalsium sebesar $11 \mathrm{mg}$, fosfor sebesar $43 \mathrm{mg}$ dan besi sebesar 1,2 mg (Departemen kesehatan RI, 1990) dibandingkan dengan buah naga merah yang mengandung kalsium sebesar 6,3-8,8 $\mathrm{mg}$; fosfor $30,2-36,1 \mathrm{mg}$ dan besi $0,55-0,65$ mg (Taiwan Food Industry Develop \& Reearch Authorities, 2005).

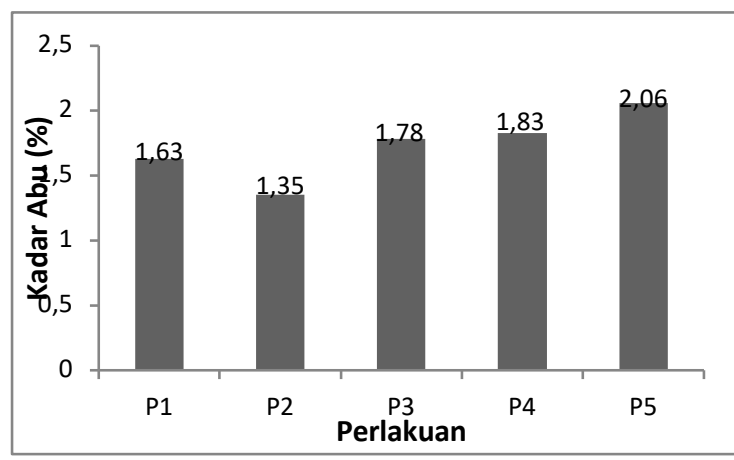

Gambar 3. Pengaruh Konsentrasii Campuran Buah Naga Merah dan Pisang Kepok Terhadap Kadar Abu Fruit Leather

Keterangan: P1: Buah naga 100\%: Pisang 0\%; P2: Buah naga 75\%: Pisang 25\%; P3: Buah naga 50\%: Pisang 50\%; P4: Buah naga 25\%: Pisang 75\%; P5: Buah naga $0 \%$ : Pisang $100 \%$

Kadar abu fruit leather buah naga merah dan buah pisang pada penelitian ini masih lebih rendah dibandingkan dengan fruit leather buah pisang kepok dari Karyantina et al. (2012) yang mencapai 3,12\%-4,5\%. Namum masih lebih tinggi dibandingkan dengan fruit leather buah naga merah dan mangga dari Ramadhan (2015) yang berkisar antara $0,40-1,02 \%$.

\section{Kadar vitamin C}

Vitamin merupakan suatu molekul organik yang sangat diperlukan tubuh untuk proses metabolisme dan pertumbuhan yang normal (Winarno, 2004). Vitamin C adalah 
Versi Online:

http://www.profood.unram.ac.id/index.php/profood e-ISSN: 2443-3446

kristal putih yang mudah larut dalam air. Vitamin C cukup stabil dalam keadaan kering, tetapi dalam keadaan larut vitamin $\mathrm{C}$ mudah rusak karena bersentuhan dengan udara terutama bila terkena panas. Vitamin C tidak stabil dalam larutan alkali, tetapi cukup stabil dalam larutan asam (Almatsier, 2003). Penelitian ini menghasilkan kadar vitamin C yang bervariasi antara 28,36\%-84,07\%. Grafik pengaruh konsentrasi campuran buah naga merah dan pisang kepok terhadap kadar vitamin C fruit leather dapat dilihat pada Gambar 4.

Gambar 4 menunjukkan bahwa semakin tinggi konsentrasi buah pisang yang ditambahkan pada fruit leather maka kadar vitamin $\mathrm{C}$ yang dihasilkan semakin rendah.

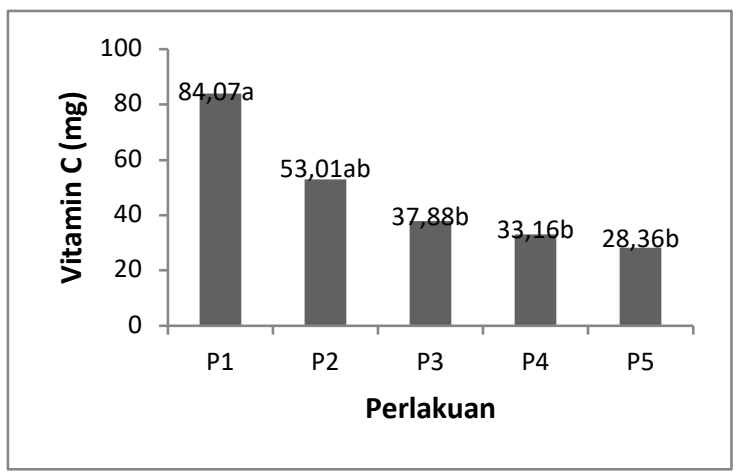

Gambar 4. Pengaruh Konsentrasi Campuran Buah Naga Merah dan Pisang Kepok Terhadap Kadar Vitamin C Fruit Leather

Keterangan: P1: Buah naga 100\%: Pisang 0\%; P2: Buah naga 75\%: Pisang 25\%; P3: Buah naga 50\%: Pisang 50\%; P4: Buah naga 25\%: Pisang 75\%; P5: Buah naga $0 \%$ : Pisang $100 \%$

Kadar vitamin C semakin menurun seiring dengan berkurangnya penambahan buah naga merah. Hal ini dikarenakan buah naga merah mengandung vitamin $\mathrm{C}$ lebih tinggi yaitu sebesar 8-9 gr/100 gr (Taiwan Food Industry Develop \& Reearch Authorities, 2005 dalam Patwary, 2013).

Selain itu hal lain yang menyebabkan rendahnya vitamin C adalah karena pembuatan fruit leather ini menggunakan buah yang sangat matang sehingga kandungan vitamin $\mathrm{C}$ semakin menurun. Nadeak dan Susanti (2012) menyatakan bahwa kandungan vitamin $\mathrm{C}$ pada buah naga
Pro Food (Jurnal Ilmu dan Teknologi Pangan)

Vol 5 No. 1 Mei 2019

ISSN: 2443-1095

merah yang masih mentah lebih tinggi dan semakin matang buah maka semakin berkurang kandungan vitamin C. Semakin tinggi tingkat kematangan buah maka kadar air, total padatan terlarut, nilai warna serta kesukaan terhadap aroma dan tekstur buah akan semakin meningkat, tetapi kandungan vitamin C, total asam, dan nilai kekerasan akan semakin menurun. Untuk menghasilkan kadar vitamin C yang optimal pada fruit leather disarankan untuk mengunakan buah yang tidak terlalu matang.

\section{KESIMPULAN}

Berdasarkan hasil penelitian dapat diambil kesimpulan yaitu:

1. Fruit leather yang memenuhi SNI untuk kadar air (maks. 25\%) adalah konsentrasi campuran pada perlakuan P1 yaitu buah naga $100 \%$ dan pisang $0 \%$, P4 yaitu buah naga $25 \%$ dan pisang $75 \%$ serta P5 yaitu buah naga 0\%: pisang 100 .

2. Berdasarkan SNI dihasilkan perlakuan terbaik (kadar air dan vitamin C) pada P1 dengan konsentrasi campuran buah buah naga $100 \%$ dan pisang $0 \%$.

\section{DAFTAR PUSTAKA}

Almatsier, S., 2003. Prinsip Dasar IImu Gizi. Gramedia Pustaka Utama. Jakarta

AOAC. 1990. Official Methods of Analysisof the Association of Analytical Chemists. Washington D.C.

Astuti, T., E. Widowati dan W. Atmaka. 2015. Kajian Karakteristik Sensoris, Fisik, Dan Kimia Fruit Leather Pisang Tanduk (Musa corniculata Lour.) Dengan Penambahan Berbagai Konsentrasi Gum Arab. Skripsi. Program Studi Teknologi Hasil Pertanian. Fakultas Pertanian. Universitas Sebelas Maret. Solo.

Cresna, M. Napitupulu dan Ratman. 2014. Analisis Vitamin C pada Buah Papaya, Sirsak dan Srikaya dan Langsat yang Tumbuh di Kabupaten Donggala. Jurnal Akademi Kimia 3(3): 121-128.

Departemen Kesehatan RI. 1990. Peraturan Menteri Kesehatan. RI No 416/Menkes/Per/IX/1990. Jakarta. 
Versi Online:

http://www.profood.unram.ac.id/index.php/profood e-ISSN: 2443-3446

Elizabeth, L. Andress, A. Judy dan Harrison. 2006. So easy to preserve. 5th Ed. Cooperative extension, University of Georgia/Athens.

Hanafiah, K.A. 2002. Rancangan Percobaan dan Teori Aplikasi. PT. Raja Grafindo Permata. Jakarta.

Karyantina, M., Linda K., dan Agus, S.W. 2014. Kajian Karakteristik Fruit Leather Dengan Variasi Jenis Pisang (Musa paradisiaca) dan Suhu Pengeringan. Skripsi. Fakultas Teknologi dan Industri Pangan Universitas Slamet Riyadi.

Nadeak, S.M.R dan D. Susanti. 2012. Variasi Temperatur dan Waktu Tahan Kalsinasi Terhadap Unjuk Kerja Semikonduktor $\mathrm{TiO}_{2}$ sebagai (DSSC) dengan Dye dari Ekstrak Buah Naga Merah. Jurnal Teknik ITS 1: 81-86.

Puspasari, K., F. Rusli., dan S. Mileiva. 2005. Formulasi Campuran Flower Leather dari Bunga Mawar dengan Ekstrak Rempah-Rempah (Cengkeh dan Kayu manis) Sebagai Pangan Fungsional Kaya Antioksidan. PKPM-2-5-1, Bogor.

Ramadhan, R.R. 2015. Kajian Pemanfatan Buah Naga Merah (Hylocereus polyrhizus) dan Mangga (Mangifera indica Linn) dalam pembuatan Fruit Leather. Jurnal Sagu, 14(1): 23-31.

Sudarmadji, S., Haryono, B. dan Suhardi. 2007. Prosedur Analisa Untuk Makanan dan Pertanian. Liberti. Yogyakarta.

Patwary, M.M.A., M.H. Rahman, H. Barua, S. Sarkar, dan M.S. Alam. 2013. Study on the Growth and Development of Two Dragon Fruit (Hylocereus undatus) Genotypes. The Agriculturists 11(2): 5257.

Praseptiangga, D., T.P. Aviany dan N.H.R. Parnanto. 2016. Pengaruh Penambahan Gum Arab Terhadap Karakteristik Fisikokimia dan Sensoris Fruit Leather Nangka (Artocarpus heterophyllus). Jurnal Teknologi Hasil Pertanian 9(1): 16.

Safitri, A.A. 2012. Studi Pembuatan Fruit Leather Mangga-Rosella. Skripsi. Jurusan Teknologi Pertanian. Fakultas Pertanian. Universitas Hasanuddin. Makassar.
Pro Food (Jurnal IImu dan Teknologi Pangan)

Vol 5 No. 1 Mei 2019

ISSN: 2443-1095

Standar Nasional Indonesia. 1996. Manisan kering buah-buahan No 01-1718. Badan Standar Nasional (BSN). Jakarta.

Wahyuni, P. T. 2015. Pengaruh Pemberian Pisang Kepok (Musa paradisiacal forma typical) Terhadap Kadar Glukosa Darah Puasa pada Tikus Sprague Dawley Prasindrom Metabolik. Artikel Penelitian. Program Studi Ilmu Gizi Fakultas Kedokteran. Universitas Diponegoro. Semarang.

Warisno dan K. Dahana. 2010. Bertanam Buah Naga. Gramedia Pustaka Utama. Jakarta.

Winarno F.G. 2004. Kimia Pangan dan Gizi. Gramedia Pustaka Utama. Jakarta.

Wu, J. and H. Prentice. 2010. Role of Taurine in The Central Nervous System. Journal Biomedical Science 17 (Suppl 1): S1. 